\title{
Design and optimization of ethanol production from bagasse pith hydrolysate by a thermotolerant yeast Kluyveromyces sp. IIPE453 using response surface methodology
}

\author{
Diptarka Dasgupta', Sunil Kumar Suman', Diwakar Pandey², Debashish Ghosh¹, Rashmi Khan', Deepti Agrawal', \\ Rakesh Kumar Jain², Vasanta Thakur Vadde ${ }^{2}$ and Dilip K Adhikari ${ }^{{ }^{*}}$
}

\begin{abstract}
Ethanol production from sugarcane bagasse pith hydrolysate by thermotolerant yeast Kluyveromyces sp. IIPE453 was analyzed using response surface methodology. Variables such as Substrate Concentration, $\mathrm{pH}$, fermentation time and $\mathrm{Na}_{2} \mathrm{HPO}_{4}$ concentration were found to influence ethanol production significantly. In a batch fermentation, optimization of key process variables resulted in maximum ethanol concentration of $17.44 \mathrm{~g} / \mathrm{L}$ which was $88 \%$ of the theoretical with specific productivity of $0.36 \mathrm{~g} / \mathrm{L} / \mathrm{h}$.
\end{abstract}

Keywords: Thermotolerant yeast, Kluyveromyces sp. IIPE453, Sugarcane bagasse pith, Response surface method

\section{Introduction}

The global scenario demonstrates that lion share of research in past three decades have been focused on technological know-how development for bioethanol since its emergence as a potential fuel additive. All the key challenges on energy and economic front have already been pinpointed in various forums as sole restrictors for commercialization of lignocellulosic bioethanol technology (Cardona et al. 2010). Evidently a non-molasses feedstock was to be brought into reality to meet excess ethanol demand for $5-10 \%$ compulsory blending. Biomass being a cheap and renewable raw material with abundant availability (Saxena et al. 2009; Kumar et al. 2009a; Cheng et al. 2008), has been considered as an excellent feedstock for bioethanol production due to its high holocellulosic content.

Ethanol production via fermentation route comprises of a series of biochemical reactions with numerous factors involved in the process. Conversion of lignocellulosic sugar hydrolysate into ethanol requires many other micro

\footnotetext{
* Correspondence: adhikari@iip.res.in

'Biotechnology Conversion Area, CSIR-Indian Institute of Petroleum, Mohkampur, Dehradun, UK-248005, India

Full list of author information is available at the end of the article
}

and macro elements apart from fermentable nitrogen which in right balance can always give optimum product yield. Statistical screening in this context provides a rapid assessment of key process variables in a systematic way whereby a perfect strategy can be materialized to improve targeted product yield. Response surface methodology (RSM) explores the relationships between several explanatory operating variables and one or more response variables and has been widely applied for optimization of ethanol production from various substrates (Uncu \& Cekmecelioglu 2011; Jargalsaikhan \& Saraçoğlu 2009).

In this paper, we have carried out RSM study of ethanol fermentation with thermotolerant yeast Kluyveromyces sp. IIPE453 (MTCC 5314) (Kumar et al. 2009b) to find optimum conditions for maximizing ethanol production via two step approach. Initial screening of factors were performed with Plackett-Burman Design (PBD) method to identify crucial parameters (Dong et al. 2012; Maruthai et al. 2012) affecting ethanol yield and to the degree based on their individual effect and interactions through Box-Behnken Design (BBD) technique (Mei et al. 2011; Palukurty et al. 2008). Further, an optimization study was conducted to maximize ethanol yield in shake flask. Optimized data has also been evaluated at bench scale 
bioreactor of $2 \mathrm{~L}$ working volume. One of the unique characteristics of Kluyveromyces sp. IIPE453 is its ability in utilizing pentose sugar for growth and fermentation with hexose sugar. Yeast cell biomass was grown with pentose rich fractions obtained after acid pretreatment of sugarcane bagasse (SCB) pith and fermented with glucose rich broth obtained after enzymatic saccharification of the pretreated pith.

An average sugarcane bagasse contains 35\% pith and with $60 \%$ depithing efficiency, around $20 \%$ pith is removed during depithing operation either at sugar mill site or at paper mill premises. An average 300 tpd (Tonne per day) bagasse based paper mill generates 160 tpd pith (Jain et al. 2011). Pretreated pith has been utilized as substrate for production of single cell proteins (Rodriguez-Vazquez et al. 1992) as well for preparation of activated carbon for dye removal from aqueous solutions (Amin 2008). However, utilization vs. generation ratio is almost negligible. Even after using as a boiler fuel in paper industry itself (calorific value of $17.07 \mathrm{Kcal} / \mathrm{Kg}$ (Diez et al. 2011)) huge amount of pith remains unutilized and poses serious waste disposal problem. Bagasse based paper mills in India annually generates $45-55$ million tons pith with a biochemical composition of holocellulose $(68-69 \% \quad \mathrm{w} / \mathrm{w})$ including hemicellulose $(20-21 \% \mathrm{w} / \mathrm{w})$, lignin $(21-22 \% \mathrm{w} / \mathrm{w})$ and ash $(6-7 \%$ w/w) (Sanjuan et al. 2001) which can be effectively used for ethanol production and thereby value addition to waste.

This study was conducted based on using this feedstock in order to integrate the process in a bio refinery mode attached with a sugar or paper and pulp industry and probably the first paper of this kind to the best of our knowledge.

\section{Materials and methods Materials}

Bagasse pith sample was generated in a depither unit with 100 mesh size at Central Pulp and Paper Research Institute (CPPRI), Saharanpur, Uttar Pradesh and used at CSIR-IIP, Dehradun for hydrolysis and saccharification. SCB pith was treated with steam and acid $\left(8 \% \mathrm{w} / \mathrm{w} \mathrm{H}_{2} \mathrm{SO}_{4}\right)$ in a solid vs. liquid ratio of $1: 10$ at $120^{\circ} \mathrm{C}$. for 90 minutes to extract pentose rich fraction $(20 \mathrm{~g} / \mathrm{L})$ which was used as carbon source for cell biomass generation. Pretreated pith devoid of pentosans was further enzymatically saccharified using commercially available cellulase (Advanced Biochemicals Ltd, Mumbai, India) to get hexose rich stream $(40 \mathrm{~g} / \mathrm{L})$ for ethanol fermentation. Saccharification was carried out using $7 \% \mathrm{w} / \mathrm{w}$ of enzyme with solid vs. liquid ratio of 1:10 at $50^{\circ} \mathrm{C}$. for $22 \mathrm{~h}$.

\section{Micro-organism and culture conditions}

Kluyveromyces sp. IIPE453 (MTCC 5314), a thermophilic yeast (optimum growth temperature $45^{\circ} \mathrm{C}$.) isolated from dumping sites of crushed SCB in a local sugar mill was used in this experimental study. The stock culture was maintained on YPD agar medium (composition in $\mathrm{g} / \mathrm{L}$; yeast extract, 10.0; peptone, 20.0; dextrose 20.0; agar agar 20.0; $\mathrm{pH} 4.5-5.0)$.

\section{Experimental design}

Growth was carried out in prehydrolysate (pentose broth) at $45^{\circ} \mathrm{C}$. for $16 \mathrm{~h}$. Nutrient screening and optimization for ethanol production were performed at same temperature in shake flasks ( $80 \mathrm{ml}$ working volume) in the hydrolysate (hexose broth) supplemented with various nutrients according to experimental design. The physical parameters,

Table 1 Plackett burman design for screening of factors

\begin{tabular}{|c|c|c|c|c|c|c|c|c|c|c|c|c|}
\hline \multirow[t]{2}{*}{ Serial } & \multirow[t]{2}{*}{$\begin{array}{l}\text { Run } \\
\text { order }\end{array}$} & \multirow[t]{2}{*}{$\mathrm{pH}$} & \multirow{2}{*}{$\begin{array}{c}\text { Inoculum } \\
\text { volume } \\
(\% \mathrm{v} / \mathrm{v})\end{array}$} & \multirow{2}{*}{$\begin{array}{l}\text { Substrate } \\
\text { conc. } \\
(g / L)\end{array}$} & \multirow{2}{*}{$\begin{array}{c}\text { Yeast } \\
\text { extract } \\
(g / L)\end{array}$} & \multirow[t]{2}{*}{$\begin{array}{c}\mathrm{MgSO}_{4} \\
(\mathrm{~g} / \mathrm{L})\end{array}$} & \multirow[t]{2}{*}{$\begin{array}{c}\left(\mathrm{NH}_{4}\right)_{2} \mathrm{SO}_{4} \\
(\mathrm{~g} / \mathrm{L})\end{array}$} & \multirow[t]{2}{*}{$\begin{array}{l}\mathrm{Na}_{2} \mathrm{HPO}_{4} \\
(\mathrm{~g} / \mathrm{L})\end{array}$} & \multirow[t]{2}{*}{$\begin{array}{l}\mathrm{KH}_{2} \mathrm{PO}_{4} \\
(\mathrm{~g} / \mathrm{L})\end{array}$} & \multirow[t]{2}{*}{$\begin{array}{l}\text { Fermentation } \\
\text { time (h) }\end{array}$} & \multicolumn{2}{|c|}{$\begin{array}{l}\text { Response variable ethanol conc. } \\
(\mathrm{g} / \mathrm{L})\end{array}$} \\
\hline & & & & & & & & & & & Experimental & Model predicted \\
\hline 1 & 1 & +1 & +1 & -1 & +1 & +1 & +1 & -1 & -1 & -1 & 7.20 & 6.91 \\
\hline 2 & 6 & -1 & -1 & -1 & +1 & -1 & +1 & +1 & -1 & +1 & 8.05 & 8.14 \\
\hline 3 & 3 & +1 & -1 & +1 & +1 & -1 & +1 & +1 & +1 & -1 & 7.18 & 7.18 \\
\hline 4 & 2 & -1 & +1 & +1 & -1 & +1 & +1 & +1 & -1 & -1 & 8.07 & 8.35 \\
\hline 5 & 4 & -1 & +1 & -1 & +1 & +1 & -1 & +1 & +1 & +1 & 7.86 & 7.76 \\
\hline 6 & 10 & -1 & +1 & +1 & +1 & -1 & -1 & -1 & +1 & -1 & 9.03 & 9.13 \\
\hline 7 & 11 & +1 & -1 & +1 & +1 & +1 & -1 & -1 & -1 & +1 & 10.09 & 10.37 \\
\hline 8 & 8 & +1 & +1 & -1 & -1 & -1 & +1 & -1 & +1 & +1 & 8.05 & 8.33 \\
\hline 9 & 9 & +1 & +1 & +1 & -1 & -1 & -1 & +1 & -1 & +1 & 7.30 & 7.02 \\
\hline 10 & 12 & -1 & -1 & -1 & -1 & -1 & -1 & -1 & -1 & -1 & 8.20 & 8.10 \\
\hline 11 & 5 & -1 & -1 & +1 & -1 & +1 & +1 & -1 & +1 & +1 & 13.40 & 13.12 \\
\hline 12 & 7 & +1 & -1 & -1 & -1 & +1 & -1 & +1 & +1 & -1 & 5.60 & 5.69 \\
\hline
\end{tabular}


Table 2 Factors with their coded levels

\begin{tabular}{clccc}
\hline $\begin{array}{c}\text { Serial } \\
\text { number }\end{array}$ & Variable & $\begin{array}{c}\text { Low } \\
(-\mathbf{1})\end{array}$ & $\begin{array}{c}\text { Center } \\
\text { point }(\mathbf{0})\end{array}$ & $\begin{array}{c}\text { High } \\
(+\mathbf{1})\end{array}$ \\
\hline 1 & $\mathrm{pH}$ & 4.5 & 5 & 5.5 \\
2 & Fermentation time (h) & 24 & 36 & 48 \\
3 & Substrate Concentration $(\mathrm{g} / \mathrm{L})$ & 20 & 30 & 40 \\
4 & Yeast extract $(\mathrm{g} / \mathrm{L})$ & 1 & 2.5 & 5 \\
5 & $\mathrm{MgSO}_{4}(\mathrm{~g} / \mathrm{L})$ & 0.06 & 0.09 & 0.12 \\
6 & $\left(\mathrm{NH}_{4}\right)_{2} \mathrm{SO}_{4}(\mathrm{~g} / \mathrm{L})$ & 1 & 3 & 5 \\
7 & $\mathrm{Na}_{2} \mathrm{HPO}_{4}(\mathrm{~g} / \mathrm{L})$ & 0.15 & 0.30 & 0.45 \\
8 & $\mathrm{KH}_{2} \mathrm{PO}_{4}(\mathrm{~g} / \mathrm{L})$ & 0.15 & 0.30 & 0.45 \\
9 & Inoculum volume $(\% \mathrm{v} / \mathrm{v})$ & 5 & 7.5 & 10 \\
\hline
\end{tabular}

$\mathrm{pH}$ and fermentation time were maintained as per design specifications (Table 1). All experiments were carried out in replicates and results are reported in terms of mean values. Experimental design and statistical analyses were done using Reliasoft Design of Experiment (DOE) software with risk factor $(\alpha)$ values of 0.05 (95\% level of confidence) for PBD and 0.01 (99\% level of confidence) for BBD. Criterion of predicted model acceptance was based on their adjusted coefficient of regression $\left(R_{a d j}^{2}\right)$ with value above 0.95 . Variables with $P$ values lower than 0.05 $(\mathrm{PBD})$ and $0.01(\mathrm{BBD})$ were considered to have significant effect on the response.

\section{Plackett burman design}

A two level PBD (Plackett \& Burman 1946) experimental matrix was set up to identify the factors and estimate their significance in ethanol production. It

Table 3 Box behnken design

\begin{tabular}{|c|c|c|c|c|c|c|c|}
\hline Run order & Random & $\begin{array}{l}\text { Substrate conc. } \\
(\mathrm{g} / \mathrm{L})(\mathrm{A})\end{array}$ & $\mathrm{pH}(\mathrm{B})$ & $\begin{array}{l}\text { Fermentation time } \\
\text { (h) (C) }\end{array}$ & $\begin{array}{l}\mathrm{Na}_{2} \mathrm{HPO}_{4} \\
(\mathrm{~g} / \mathrm{L})(\mathrm{D})\end{array}$ & $\begin{array}{c}\text { Experimental ethanol } \\
\text { conc. (g/L) }\end{array}$ & $\begin{array}{l}\text { Model predicted ethanol } \\
\text { conc. (g/L) }\end{array}$ \\
\hline 1 & 15 & 0 & -1 & 0 & +1 & 10.90 & 10.32 \\
\hline 2 & 14 & 0 & +1 & 0 & -1 & 8.60 & 7.79 \\
\hline 3 & 9 & -1 & 0 & -1 & 0 & 4.20 & 3.95 \\
\hline 4 & 12 & +1 & 0 & +1 & 0 & 11.55 & 12.07 \\
\hline 5 & 4 & +1 & +1 & 0 & 0 & 7.10 & 6.91 \\
\hline 6 & 17 & -1 & 0 & 0 & -1 & 9.30 & 9.34 \\
\hline 7 & 19 & -1 & 0 & 0 & +1 & 4.40 & 4.35 \\
\hline 8 & 20 & +1 & 0 & 0 & +1 & 11.50 & 11.47 \\
\hline 9 & 24 & 0 & +1 & +1 & 0 & 7.90 & 7.45 \\
\hline 10 & 7 & 0 & 0 & -1 & +1 & 7.25 & 7.37 \\
\hline 11 & 25 & 0 & 0 & 0 & 0 & 7.60 & 8.01 \\
\hline 12 & 11 & 0 & 0 & +1 & 0 & 8.32 & 7.65 \\
\hline 13 & 2 & +1 & -1 & 0 & 0 & 14.60 & 13.53 \\
\hline 14 & 13 & 0 & -1 & 0 & -1 & 12.70 & 12.61 \\
\hline 15 & 8 & 0 & 0 & +1 & +1 & 8.00 & 8.45 \\
\hline 16 & 10 & +1 & 0 & -1 & 0 & 8.10 & 8.37 \\
\hline 17 & 23 & 0 & -1 & +1 & 0 & 12.00 & 12.27 \\
\hline 18 & 3 & -1 & +1 & 0 & 0 & 3.60 & 4.29 \\
\hline 19 & 1 & -1 & -1 & 0 & 0 & 7.50 & 7.31 \\
\hline 20 & 21 & 0 & -1 & -1 & 0 & 7.90 & 8.57 \\
\hline 21 & 5 & 0 & 0 & -1 & -1 & 6.80 & 7.04 \\
\hline 22 & 6 & 0 & 0 & +1 & -1 & 12.80 & 13.36 \\
\hline 23 & 18 & +1 & 0 & 0 & -1 & 11.00 & 11.06 \\
\hline 24 & 26 & 0 & 0 & 0 & 0 & 8.00 & 8.01 \\
\hline 25 & 16 & 0 & +1 & 0 & +1 & 5.40 & 5.50 \\
\hline 26 & 27 & 0 & 0 & 0 & 0 & 7.70 & 8.01 \\
\hline 27 & 22 & 0 & +1 & -1 & 0 & 4.10 & 3.75 \\
\hline
\end{tabular}


predicts linear model where only main effects are taken into consideration.

$$
\text { Response }=\mathrm{a}+\sum \mathrm{b}_{\mathrm{i}}{ }^{*} \mathrm{X}_{\mathrm{i}}
$$

Response indicates dependent variable in terms of overall ethanol production $(\mathrm{g} / \mathrm{L})$, a being the model intercept. $\mathbf{X}_{\mathbf{i}}$ represents different levels of independent variables with $\mathbf{b}_{\mathbf{i}}$ coefficients as predicted by the equation. In this paper, 9 independent variables were selected, e.g. physical parameters such as $\mathrm{pH}$, fermentation time, inoculum volume $(\% \mathrm{v} / \mathrm{v})$ and media components such as sugar concentration, yeast extract, magnesium sulphate $\left[\mathrm{MgSO}_{4}\right]$, ammonium sulphate $\left[\left(\mathrm{NH}_{4}\right)_{2} \mathrm{SO}_{4}\right]$, disodium hydrogen phosphate $\left[\mathrm{Na}_{2} \mathrm{HPO}_{4}\right]$ and potassium di-hydrogen phosphate $\left[\mathrm{KH}_{2} \mathrm{PO}_{4}\right]$. Table 1 illustrates the design matrix of various components with coded values; low $(-1)$ and high $(+1)$ while Table 2 represents their actual values. Pareto charts were plotted to highlight most significant factors responsible for ethanol production.

\section{$B B D$ design and optimization}

$B B D$ technique is a statistical indication of quadratic effect factors obtained after initial factorial screening studies and their interactions (Box \& Behnken 1960). Based on Pareto chart results, BBD matrix was constructed with four significant factors (substrate concentration, $\mathrm{pH}$, fermentation time and $\mathrm{Na}_{2} \mathrm{HPO}_{4}$ concentration) each having 3 levels $(-1,0$ and 1$)$ with 27 experimental designs as shown in Table 3. Rest non-significant factors namely Inoculum volume, Yeast extract, $\mathrm{MgSO}_{4},\left(\mathrm{NH}_{4}\right)_{2} \mathrm{SO}_{4}$ and $\mathrm{KH}_{2} \mathrm{PO}_{4}$ were maintained at their respective low level values (Table 2). A second order polynomial model was predicted with DOE (equation 2) indicating linear, interaction and quadratic effect of variables on system response as either + ve or -ve. ANOVA analysis of the model was performed to evaluate its statistical significance.

$$
\begin{aligned}
\text { Response }= & \mathrm{a}_{1}+\mathrm{b}_{1} * \mathrm{~A}+\mathrm{b}_{2} * \mathrm{~B}+\mathrm{b}_{3} * \mathrm{C}+\mathrm{b}_{4} * \mathrm{D} \\
& +\mathrm{b}_{5} * \mathrm{~A} * \mathrm{~B}+\mathrm{b}_{6} * \mathrm{~A} * \mathrm{C}+\mathrm{b}_{7} * \mathrm{~A} * \mathrm{D} \\
& +\mathrm{b}_{8} * \mathrm{~B} * \mathrm{C}+\mathrm{b}_{9} * \mathrm{~B} * \mathrm{D}+\mathrm{b}_{10} * \mathrm{C} * \mathrm{D} \\
& +\mathrm{b}_{11} * \mathrm{~A}^{2}+\mathrm{b}_{12} * \mathrm{~B}^{2}+\mathrm{b}_{13} * \mathrm{C}^{2}+\mathrm{b}_{14} * \mathrm{D}^{2}
\end{aligned}
$$

where, $\mathrm{A}, \mathrm{B}, \mathrm{C}$ and $\mathrm{D}$ are the independent variables, $\mathrm{a}_{1}$ is an offset term, $b_{1}$ to $b_{4}$ are linear term coefficients, $b_{5}$

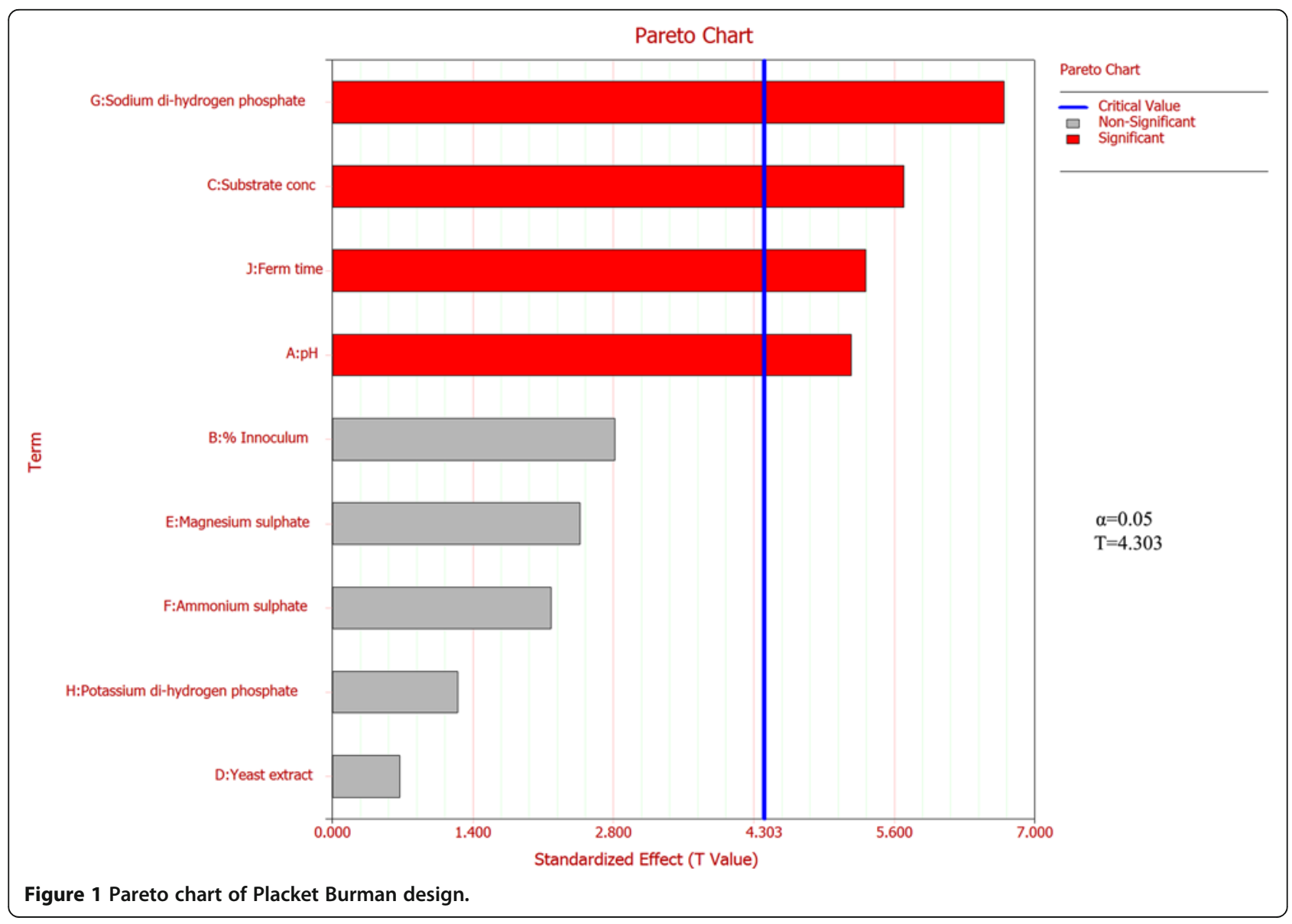


Table 4 Regression analysis for Plackett Burman design variables

\begin{tabular}{cccccc}
\hline Term & Effect & Coefficient & Standard error & T value & P value \\
\hline Intercept & & $\mathbf{8 . 3 3 7 6}$ & $\mathbf{0 . 1 4 8 1}$ & $\mathbf{5 6 . 2 9 6}$ & $\mathbf{0 . 0 0 0 3}$ \\
$\mathbf{p H}$ & $\mathbf{- 1 . 5 3 2 2}$ & $-\mathbf{0 . 7 6 6 1}$ & $\mathbf{0 . 1 4 8 1}$ & $\mathbf{- 5 . 1 7 2 6}$ & $\mathbf{0 . 0 3 5 4}$ \\
\% Inoculum $(\mathrm{V} / \mathrm{v})$ & -0.8345 & -0.4173 & 0.1481 & -2.8174 & $\mathbf{0 . 1 0 6 3}$ \\
Substrate conc. & $\mathbf{1 . 6 8 8 3}$ & $\mathbf{0 . 8 4 4 1}$ & $\mathbf{0 . 1 4 8 1}$ & $\mathbf{5 . 6 9 9 7}$ & -0.6734 \\
Yeast extract & -0.1995 & -0.0997 & 0.1481 & 0.5701 \\
Magnesium sulphate & 0.7329 & 0.3665 & 0.1481 & 0.1318 \\
Ammonium sulphate & 0.6458 & 0.3229 & $\mathbf{0 . 1 4 8 1}$ & $\mathbf{0 . 1 8 0 3}$ & $\mathbf{0 . 1 6 1}$ \\
Sodium di-hydrogen phosphate & $\mathbf{- 1 . 9 8 4}$ & $-\mathbf{0 . 9 9 2}$ & $\mathbf{- 6 . 6 9 8 2}$ & $\mathbf{0 . 0 2 1 6}$ \\
Potassium di-hydrogen phosphate & 0.3705 & 0.1853 & $\mathbf{0 . 1 4 8 1}$ & $\mathbf{0 . 1 4 8 1}$ & $\mathbf{5 . 3 1 7 4}$ \\
Fermentation time & $\mathbf{1 . 5 7 5 1}$ & $\mathbf{0 . 7 8 7 5}$ & & $\mathbf{0 . 0 3 3 6}$ \\
\hline
\end{tabular}

to $b_{10}$ indicate interaction terms and $b_{11}$ to $b_{14}$ represent quadratic effect.

\section{Model validation in shake flask and scale up study in} bench scale bioreactor

BBD predicted response led to identification of optimization conditions in terms of key independent variables having significant effect on system response. To validate authenticity of software generated model, fermentation was carried out in shake flask under optimized conditions and further tested on a $2 \mathrm{~L}$ bench scale bioreactor (NBS Bioflo 110) equipped with supervisory control and data acquisition (SCADA) system. Yeast biomass generated on prehydrolysate $(20 \mathrm{~g} / \mathrm{L}$ pentose conc.) was inoculated in fermentation broth having SCB pith hydrolysate $(40 \mathrm{~g} / \mathrm{L}$ glucose conc.) in shake flask as per model predicted optimized conditions as well as in 2 L NBS bioflo110.

\section{Analytical methods}

Sugar and ethanol concentration $(\mathrm{g} / \mathrm{L})$ was quantified by HPLC (UFLC Shimadzu) with PL Hiplex-H acid $8 \mu \mathrm{m}$ column $(100 \times 7.7 \mathrm{~mm}$ diameter, by PL Polymer laboratory, UK). The column was eluted with a mobile phase $1 \mathrm{mM}$ sulfuric acid at a flow rate of $0.7 \mathrm{ml} / \mathrm{min}$ at column oven temperature $57^{\circ} \mathrm{C}$. with RI detector.

\section{Results and discussion}

Evaluation of key variables affecting ethanol production

Lignocellulosic ethanol production requires various micro and macro elements along with fermentable sugar and nitrogen which in best commingle results in optimum product yield where a controlled environment is again a prerequisite (Asli 2009; Anupama et al. 2010). Magnesium, being the cofactor for glycolytic enzymes involved in fermentation (Lodolo et al. 2008) and potassium being the regulator of $\mathrm{pH}$ via $\mathrm{K}^{+} / \mathrm{H}^{+}$transport system, (Kudo et al. 1998) are essential cations governing ethanol fermentation. Ammonium salts stimulate glucose fermentation by lowering induction period (Muntz 1947) and maintaining an optimum carbon to nitrogen $(\mathrm{C} / \mathrm{N})$ ratio. Substrate concentration primarily affects uptake rates and thereby product rate kinetics. High substrate concentration negatively hampers ethanol productivity leading to a lower titer due to repression of glycolytic enzymes (Bisson \& Fraenkel 1984). Yeast extract is a rich source of vitamins and promotes cell growth and proliferation. Hence, the above mentioned variables have been chosen to screen and develop a low cost fermentation medium with optimum blend of nutrients and physical parameters for bioethanol production.

PBD identified the key variables among selected ones via Pareto chart illustrated in Figure 1. Factors such as $\mathrm{pH}$, fermentation time, substrate concentration and

Table 5 ANOVA table for BBD model

\begin{tabular}{|c|c|c|c|c|c|}
\hline Source of variation & Degrees of freedom & Sum of squares [Partial] & Mean squares [Partial] & $\mathrm{F}$ ratio & $P$ value \\
\hline Model & 14 & 211.4135 & 15.101 & 49.2852 & $2.11 \mathrm{E}-08$ \\
\hline Linear Effects & 4 & 185.1535 & 46.2884 & 151.072 & $3.75 \mathrm{E}-10$ \\
\hline Interaction Effects & 6 & 18.0454 & 3.0076 & 9.8158 & 0.0005 \\
\hline Quadratic Effects & 4 & 8.2146 & 2.0537 & 6.7026 & 0.0045 \\
\hline Residual & 12 & 3.6768 & 0.3064 & & \\
\hline Lack of Fit & 10 & 3.5901 & 0.359 & 8.2849 & 0.1124 \\
\hline Pure Error & 2 & 0.0867 & 0.0433 & & \\
\hline Total & 26 & 215.0903 & & & \\
\hline
\end{tabular}


Table 6 Significance of term coefficients for BBD

\begin{tabular}{|c|c|c|c|c|}
\hline Term & Coefficient & Standard error & $\mathrm{T}$ value & $P$ value \\
\hline Intercept & 7.7667 & 0.3196 & 24.3025 & $1.42 \mathrm{E}-11$ \\
\hline A & 2.2108 & 0.1598 & 13.8358 & $9.75 \mathrm{E}-09$ \\
\hline B & -2.4083 & 0.1598 & -15.0717 & $3.68 \mathrm{E}-09$ \\
\hline C & 1.8517 & 0.1598 & 11.588 & 7.13E-08 \\
\hline D & -1.1458 & 0.1598 & -7.1708 & 1.13E-05 \\
\hline$A * B$ & -0.9 & 0.2768 & -3.2518 & 0.0069 \\
\hline$A^{*} \mathrm{C}$ & -0.1675 & 0.2768 & -0.6052 & 0.5563 \\
\hline$A * D$ & 1.35 & 0.2768 & 4.8778 & 0.0004 \\
\hline$B^{*} C$ & -0.075 & 0.2768 & -0.271 & 0.791 \\
\hline$B^{*} D$ & -0.35 & 0.2768 & -1.2646 & 0.23 \\
\hline$C * D$ & -1.3125 & 0.2768 & -4.7423 & 0.0005 \\
\hline$A^{2}$ & 0.1996 & 0.2397 & 0.8327 & 0.4213 \\
\hline$B^{2}$ & 0.3408 & 0.2397 & 1.422 & 0.1805 \\
\hline$C^{2}$ & -0.0817 & 0.2397 & -0.3407 & 0.7392 \\
\hline$D^{2}$ & 1.1346 & 0.2397 & 4.7336 & 0.0005 \\
\hline $\begin{array}{l}\text { A: Substra } \\
\text { C: Fermen }\end{array}$ & n time (h) & & $\mathrm{Na}_{2} \mathrm{HPO}_{4} \mathrm{C}$ & (g/L) \\
\hline
\end{tabular}

$\mathrm{Na}_{2} \mathrm{HPO}_{4}$ with $\mathrm{T}$ values above threshold (4.30 in this case) and $\mathrm{P}$ values lower than 0.05 as represented by regression analysis (Table 4) had a substantial effect on ethanol yield and were considered for further evaluation by BBD, while rest of the variables did not have a meaningful contribution to ethanol production. Fermentation process is directly affected by the amount of viable cells present in broth. An optimum inoculum volume of 5\% $(\mathrm{v} / \mathrm{v})$ was sufficient to carry out the fermentation process.
Higher concentration of the same had no effect on ethanol yield improvement and thus was considered to be non-significant variable in the process (Figure 1). The model considering main effects (equation not shown) was found to be fairly accurate having a $R^{2}$ value of 0.98 with a $R_{\text {adj }}^{2}$ value of 0.92 with experimental and model predicted response being fairly close to each other.

\section{Optimization of physical parameters and media} components for ethanol production

BBD matrix with response is shown in Table 3. A second order polynomial model fit to the experimental data for optimizing ethanol production via response surface method (RSM) predicts response as a function of four variables and their interactions in terms of their coded values.

$$
\begin{aligned}
\text { Response }= & 7.67+2.21 * \mathrm{~A}-2.40 * \mathrm{~B}+1.81 * \mathrm{C} \\
& -1.14 * \mathrm{D}-0.90 * \mathrm{~A} * \mathrm{~B}-0.1675^{*} \mathrm{~A} * \mathrm{C} \\
& +1.35 * \mathrm{~A} * \mathrm{D}-0.07 * \mathrm{~B} * \mathrm{C} \\
& -0.35^{*} \mathrm{~B} * \mathrm{D}-1.31 * \mathrm{C} * \mathrm{D}+0.19^{*} \mathrm{~A}^{2} \\
& +0.34 * \mathrm{~B}^{2}-0.08 * \mathrm{C}^{2}+1.13 * \mathrm{D}^{2}
\end{aligned}
$$

ANOVA calculations listed in Table 5 show that the model $\mathrm{F}$ and $\mathrm{P}$ values are 49.252 and $2.11 \times 10^{-8}$. This signifies the model with $99 \%$ level of confidence $(\alpha=0.01)$ and all effects namely linear, interaction and quadratic are exhibited. Quality of fit model was estimated by $R_{\text {adj }}^{2}$ and predicted $R^{2}\left(R_{\text {pred }}^{2}\right)$ values were found

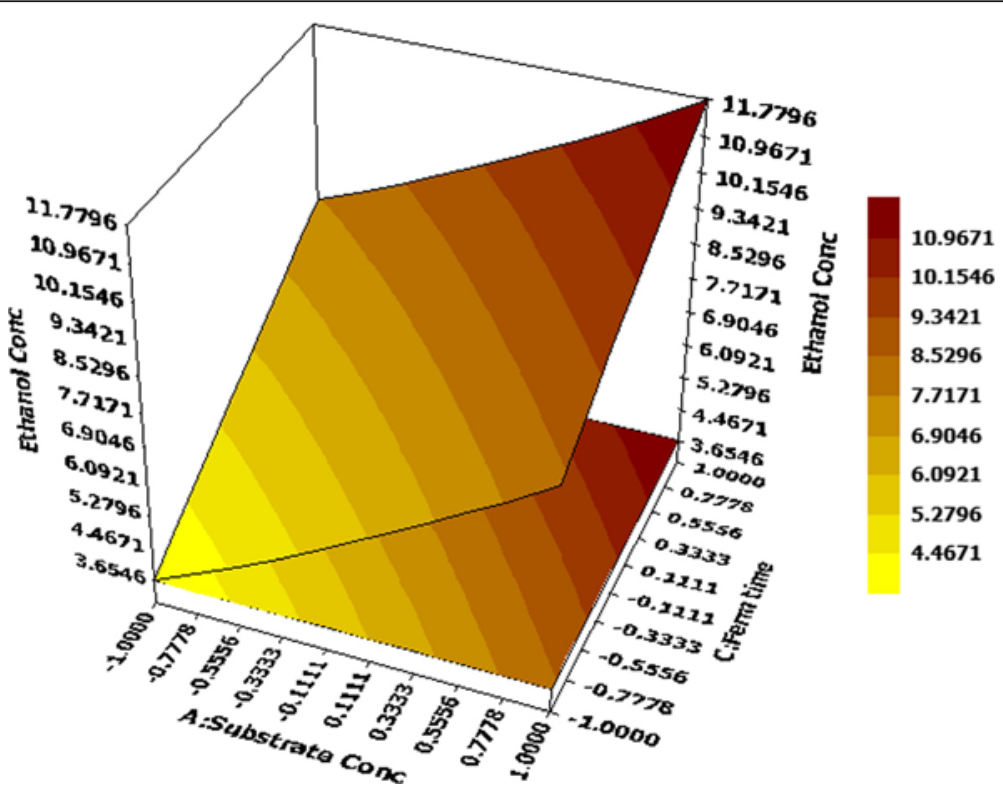

Figure 2 Effects of substrate concentration and fermentation time on ethanol production hold values: $B=0(p H=5.0), D=0$ $\left(\mathrm{Na}_{2} \mathrm{HPO}_{4}=0.15 \mathrm{~g} / \mathrm{L}\right)$. 


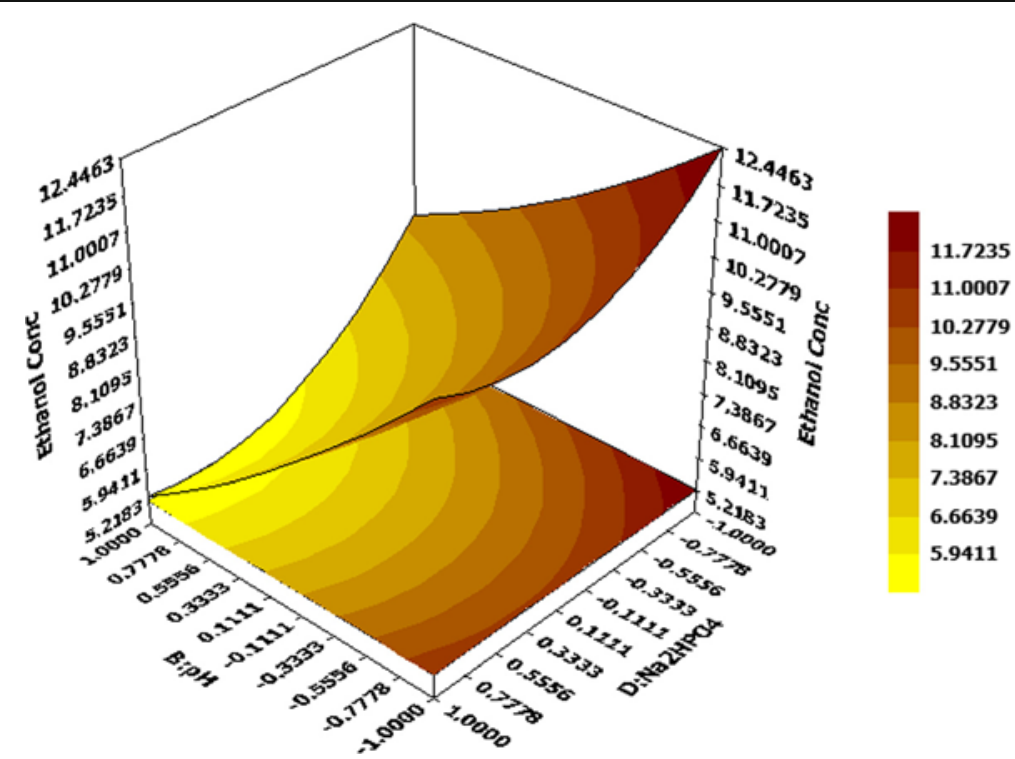

Figure 3 Effects of $\mathrm{pH}$ and $\mathrm{Na}_{2} \mathrm{HPO}_{4}$ concentration on ethanol production hold values: $\mathrm{A}=0$ (substrate Conc. $=30 \mathrm{~g} / \mathrm{L}$ ), $\mathrm{C}=0$ (fermentation time $=36 \mathrm{~h}$ ).

to be 0.96 and 0.90 respectively which are fairly high and accurate measures of precision (Ohtani 2000). This indicates that only $4 \%$ variation in response cannot be suitably explained by the model. Response values for each run calculated by developed model showed little or no variation compared to test results. This indicated that model equation very well corresponded to BBD experimental data. Statistical significance of the model term coefficients was determined by student's $t$-test and $p$ test values as illustrated in Table 6 . It was observed that main effects were significant for each of four coded factors whereas interactions among $\mathrm{pH}$ and substrate concen- tration, substrate concentration \& $\mathrm{Na}_{2} \mathrm{HPO}_{4}$ concentration, fermentation time \& $\mathrm{Na}_{2} \mathrm{HPO}_{4}$ concentration were important as indicated by their high $\mathrm{T}$ and low $\mathrm{P}$ values.

3D response surface graphs display the characteristic effects of key process variables on ethanol concentration. Figure 2 demonstrates the response against substrate concentration and fermentation time while other two factors namely $\mathrm{pH}$ and $\mathrm{Na}_{2} \mathrm{HPO}_{4}$ concentration are maintained at their centre point values $(0,0)$, i.e. 5 and $0.30 \mathrm{~g} / \mathrm{L}$. The linear surface exhibits a greater first degree effect of both independent variables on system response. An increase in both factors lead to enhanced

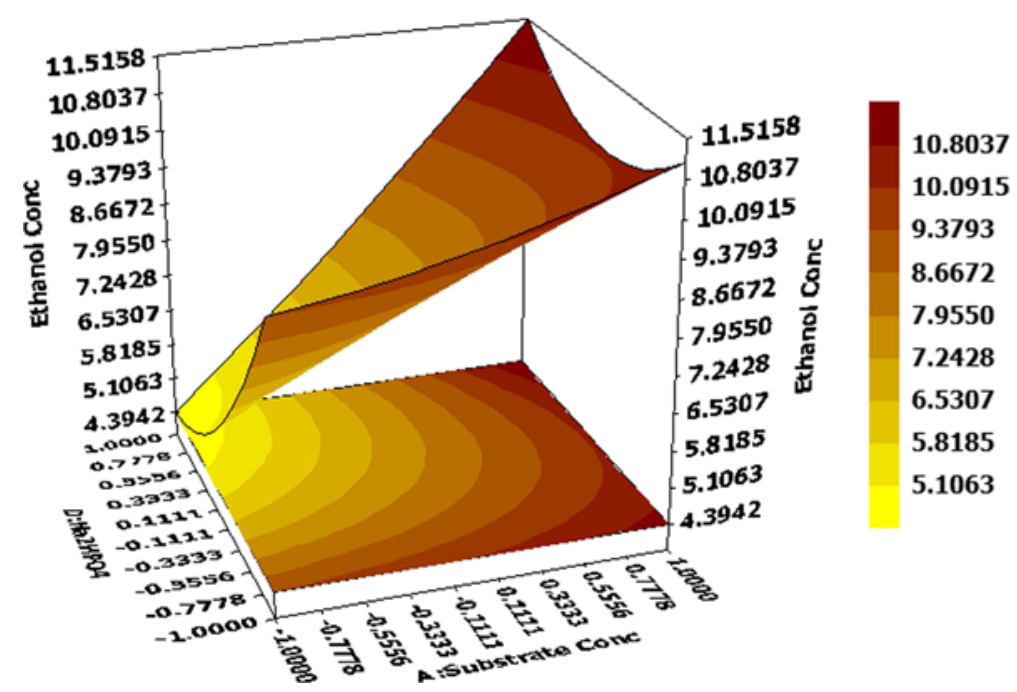

Figure 4 Effects of substrate concentration and $\mathrm{Na}_{2} \mathrm{HPO}_{4}$ concentration on ethanol production hold values: $\mathrm{B}=0(\mathrm{pH}=5.0), \mathrm{C}=0$ (fermentation time $=36$ hours). 


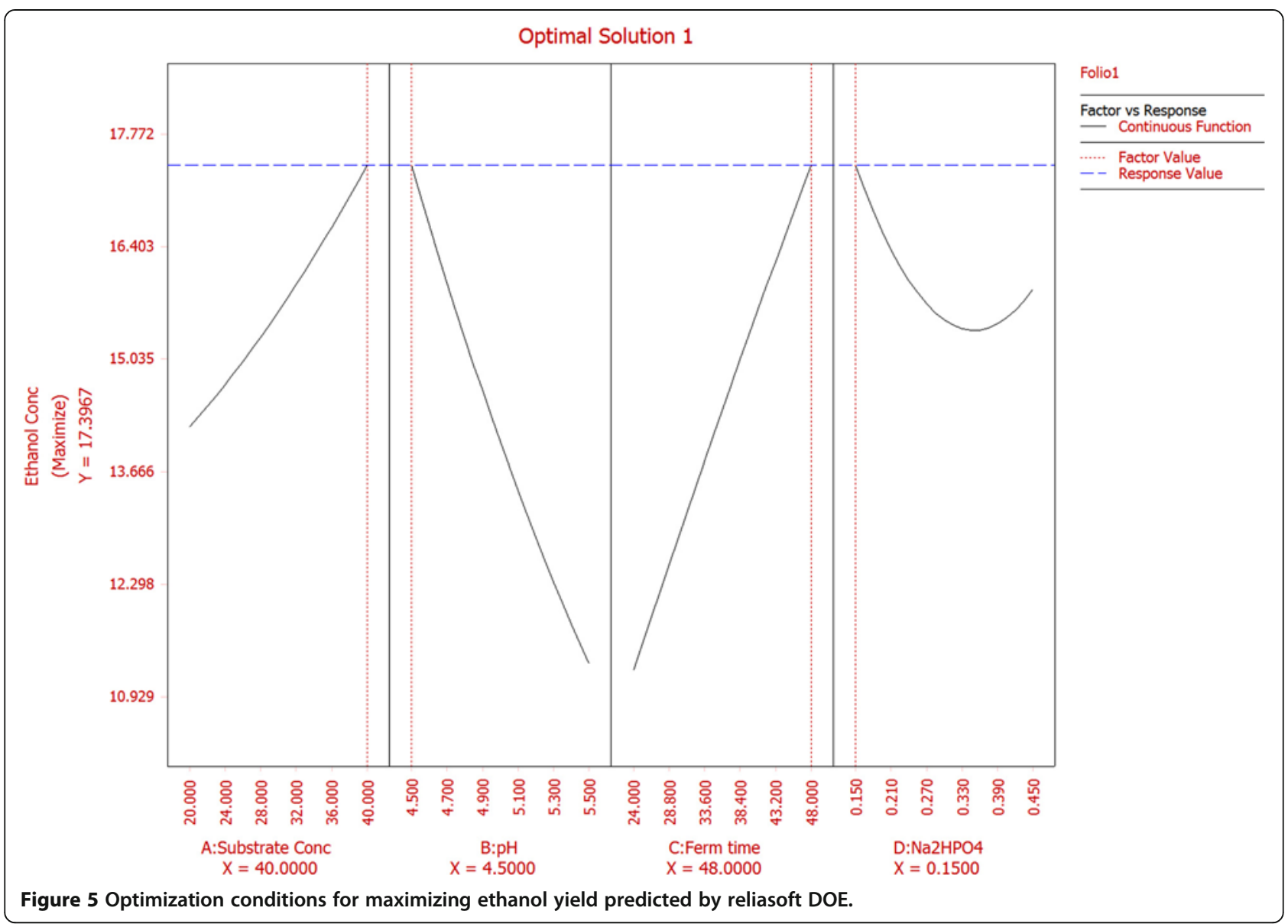

ethanol yield, maximum being $11.77 \mathrm{~g} / \mathrm{L}$ at 48 hour and $40 \mathrm{~g} / \mathrm{L}$ of substrate concentration and decrease in ethanol yield on reduction of the same. Thus, both factors have a positive effect on the dependent variable. On the contrary, effects of $\mathrm{Na}_{2} \mathrm{HPO}_{4}$ concentration and $\mathrm{pH}$ at hold values for substrate concentration $(30 \mathrm{~g} / \mathrm{L})$ and fermentation time $(36 \mathrm{~h})$ illustrate that system should be maintained at low values for both variables to attain maximum ethanol production (Figure 3 ). The surface is more concave nature in this case compared to Figure 2

Table 7 Comparative analysis of different ethanol processes with lignocellulosic/waste material

\begin{tabular}{|c|c|c|c|c|c|c|c|c|c|c|}
\hline SI \# & $\begin{array}{c}\text { Lignocellulosic/ } \\
\text { waste raw } \\
\text { material }\end{array}$ & Strain used & $\begin{array}{c}\text { Temperature } \\
\left({ }^{\circ} \mathrm{C}\right)\end{array}$ & $\mathrm{pH}$ & $\begin{array}{l}\text { Sugar } \\
\text { conc. } \\
\text { (g/L) }\end{array}$ & $\begin{array}{l}\text { Ethanol } \\
\text { conc. } \\
\text { (g/L) }\end{array}$ & $\begin{array}{l}\text { Inoculum } \\
\text { volume } \\
(\% \mathrm{v} / \mathrm{v})\end{array}$ & $\begin{array}{c}\text { Yield (\% } \\
\text { theoretical) }\end{array}$ & $\begin{array}{l}\text { Productivity } \\
\text { (g/L/h) }\end{array}$ & Reference \\
\hline 1 & $\begin{array}{l}\text { Bagasse pith } \\
\text { hydrolysate }\end{array}$ & $\begin{array}{l}\text { Kluyveromyces } \\
\text { sp. IIPE453 }\end{array}$ & 45 & 4.5 & 40 & 17.40 & 5 & 88 & 0.36 & this paper \\
\hline 2 & Softwood & $\begin{array}{c}\text { Pichiastipitis CBS6054: } \\
\text { S. cerevisiae Y5 }\end{array}$ & 30 & 5.0 & 65 & 27.40 & - & 85.1 & 0.28 & (Wan et al. 2012) \\
\hline 3 & $\begin{array}{c}\text { Kinnow waste } \\
\text { and banana } \\
\text { peels }\end{array}$ & $\begin{array}{c}\text { Consortia of } \\
\text { Pachysolentannophilus } \\
\text { (MTCC 1077) and } \\
\text { S. cerevisiae G }\end{array}$ & 30 & - & 63 & 26.84 & $4: 6$ & 83.5 & 0.55 & (Han et al. 2011) \\
\hline 4 & $\begin{array}{l}\text { Sugarcane } \\
\text { bagasse }\end{array}$ & Kluyveromyces fragilis & 35 & 5.5 & 180 & 32.60 & - & 36 & 0.45 & (Sharma et al. 2007) \\
\hline 5 & $\begin{array}{l}\text { Korean food } \\
\text { waste }\end{array}$ & S. cerevisiae 7904 & 35 & 5.4 & 75 & 24.17 & 2.5 & 63 & 0.60 & $\begin{array}{c}\text { (Sasikumar \& } \\
\text { Viruthagiri 2008) }\end{array}$ \\
\hline 6 & Tapioca stem & Fusarium oxysporum & 30 & 5.5 & 33 & 8.64 & 2 & 51.33 & 0.05 & (Man et al. 2010) \\
\hline 7 & $\begin{array}{l}\text { Miscanthus } \\
\text { biomass }\end{array}$ & S. cerevisae & 32 & - & 140 & 59.20 & 7 & 83.92 & 1.23 & (Magesh et al. 2011) \\
\hline
\end{tabular}


and represents quadratic and interaction effects in addition to linear ones with maximum ethanol concentration of $12.44 \mathrm{~g} / \mathrm{L}$ at $\mathrm{pH} 4.5$ and $\mathrm{Na}_{2} \mathrm{HPO}_{4}$ concentration $0.15 \mathrm{~g} / \mathrm{L}$. Effect of substrate concentration and $\mathrm{Na}_{2} \mathrm{HPO}_{4}$ concentration on ethanol production at a fixed $\mathrm{pH}$ value of 5 and $36 \mathrm{~h}$ fermentation time is depicted in Figure 4. It demonstrates that $\mathrm{Na}_{2} \mathrm{HPO}_{4}$ and substrate concentration at their maximum values $0.45 \mathrm{~g} / \mathrm{L}$ and $40 \mathrm{~g} / \mathrm{L}$ respectively, lead to maximum ethanol production of $11.51 \mathrm{~g} / \mathrm{L}$ whereas $\mathrm{Na}_{2} \mathrm{HPO}_{4}$ concentration at its' lowest value $(0.15 \mathrm{~g} / \mathrm{L})$ with same substrate concentration yields almost same ethanol $(11.15 \mathrm{~g} / \mathrm{L})$. Hence, ethanol production is more sensitive to changes in substrate concentration compared to $\mathrm{Na}_{2} \mathrm{HPO}_{4}$ concentration when other two variables $\mathrm{pH}$ and fermentation time are fixed at their midpoint values. However, interaction effects between these two are + ve and statistically significant as predicted by the model equation for considerable ethanol yield. Based on polynomial model, optimization study was carried out for maximizing ethanol production. Maximum ethanol concentration predicted by the model was found to be $17.39 \mathrm{~g} / \mathrm{L}$ with $40 \mathrm{~g} / \mathrm{L}(+1)$ substrate concentration, $\mathrm{pH} 4.5(-1), 48 \mathrm{~h}(+1)$ fermentation time and $0.15 \mathrm{~g} / \mathrm{L}(-1) \mathrm{Na}_{2} \mathrm{HPO}_{4}$ (Figure 5). The data was further validated in a shake flask study where the experiment was carried out under optimized condition.

\section{Scale up study in bench scale bioreactor}

Scale up study was conducted in bioreactor with optimized conditions yielding $17.44 \mathrm{~g} / \mathrm{L}$ of ethanol which is almost identical to the model predicted value with residual hexose concentration of $1.2 \mathrm{~g} / \mathrm{L}$ in the hydrolysate. This validated the accuracy of predicted model and confirmation of an optimum point within system for achieving targeted ethanol production. The ethanol yield $\left(\mathrm{Y}_{\mathrm{p} / \mathrm{S}}\right)$ in terms of consumed sugar was $88 \%$ of theoretical value with specific ethanol productivity of $0.36 \mathrm{~g} / \mathrm{L} / \mathrm{h}$.

\section{Conclusion}

Identification and optimization of key process variables for ethanol production from SCB pith hydrolysate could successfully be achieved using PBD and RSM. Four variables namely Substrate Conc., $\mathrm{pH}$, fermentation time and $\mathrm{Na}_{2} \mathrm{HPO}_{4}$ were most significant factors affecting ethanol production. Final ethanol concentration and yield attained under optimum fermentation conditions was $17.44 \mathrm{~g} / \mathrm{L}$ and $88 \%$ of theoretical value which was identical to the model predicted response. The ethanol yield, productivity and fermentation conditions for ethanol production from SCB pith via this process was compared with other other lignocellulosic bioethanol processes (Table 7) with different fermenting strains. The ethanol yield obtained with the current process is found to be significantly high in comparison to other processes utilizing different lignocellulosic/waste feedstocks for bioethanol production.

\section{Competing interests}

The authors declare that they have no competing interests.

\section{Authors' contributions}

DDG and SKS designed and conducted research (project conception, development of overall research plan, study oversight, hands-on conduct of the experiments and data collection) and performed statistical analysis along with drafting of the manuscript; DG had primary responsibility of data representation and final shaping of the manuscript; RK carried out cell culture maintenance and inoculum preparation; DP and RKJ carried out prehydrolysis of bagasse pith; DA and VTV carried out enzymatic saccharification of pretreated bagasse pith for fermentation study; DKA supervised overall work and participated in result interpretation with DDG, SKS and DG; DKA is also the corresponding author. All authors read and approved the final manuscript.

\section{Acknowledgement}

Grant from CESS-CPPRI is sincerely acknowledged. Authors are also thoroughly grateful to Dr. MO Garg, Director, CSIR-IIP and Dr. RM Mathur, Director, CPPRI for providing necessary facilities and constant support.

\section{Author details}

${ }^{1}$ Biotechnology Conversion Area, CSIR-Indian Institute of Petroleum, Mohkampur, Dehradun, UK-248005, India. 'Division of Chemical Recovery, Central Pulp and Paper Research Institute, Biotechnology \& Lignin byproducts, Saharanpur, UP-247001, India.

Received: 9 January 2013 Accepted: 4 April 2013

Published: 15 April 2013

\section{References}

Amin NK (2008) Removal of reactive dye from aqueous solutions by adsorption onto activated carbons prepared from sugarcane bagasse pith. Desalination 223:152-161

Anupama MP, Mahesh DG, Ayyanna C (2010) Optimization of fermentation medium for the production of ethanol from jaggery using box-behnken design. Int J Appl Biol Pharm Technol 1:34-45

Asli MS (2009) A study on some efficient parameters in batch fermentation of ethanol using Saccharomyces cerevesiae SC1 extracted from fermented siahesardasht pomace. Afr J Biotechnol 9:2906-2912

Bisson LF, Fraenkel DG (1984) Expression of kinase dependent glucose uptake in Saccharomyces cerevisae. J Bacteriol 159:1013-1017

Box GEP, Behnken DW (1960) Some new three level designs for the study of quantitative variables. Technometrics 2:455-475

Cardona CA, Quintero JA, Paz IC (2010) Production of bioethanol from sugarcane bagasse: status and perspectives. Bioresour Technol 101:4754-4766

Cheng KK, Cai BY, Zhang JA, Ling HZ, Zhou YJ, Ge JP, Xu JM (2008) Sugarcane bagasse hemicellulose hydrolysate for ethanol production by acid recovery process. Biochem Eng J 38:105-109

Diez OA, Càrdenas GJ, Mentz LF (2011) Calorific value of sugarcane bagasse, pith and their blends (Tucumàn, Argentine Republic). Rev indagric Tucumán 87:29-38

Dong Y, Zhang N, Lu J, Lin F, Teng L (2012) Improvement and optimization of the media of Saccharomyces cerevisae strain for high tolerance and high yield of ethanol. Afr J Biotechnol 6:2357-2366

Han M, Choi G-W, Kim Y, Koo B-C (2011) Bioethanol production by miscanthus as a lignocellulosic biomass: focus on high efficiency conversion to glucose and ethanol. Bioresources 6:1939-1953

Jain RK, Thakur W, Pandey D, Adhikari DK, Dixit AK, Mathur RM (2011) Bioethanol from bagasse pith a lignocellulosic waste biomass from paper/sugar industry. IPPTA 23:169-173

Jargalsaikhan O, Saraçoğlu N (2009) Application of experimental design method for ethanol production by fermentation of sunflower seed hull hydrolysate using Pichiastipitis NRRL-124. Chem Eng Comm 196:93-103

Kudo M, Vagnoli P, Bisson LF (1998) Imbalance of $\mathrm{pH}$ and potassium concentration as a cause of stuck fermentations. Am J Enol Vitic 49:295-301

Kumar P, Barett DM, Delwiche MJ, Stroeve P (2009a) Methods for pretreatment of lignocellulosic biomass for efficient hydrolysis and biofuel production. Ind Eng Chem Res 48:3713-3729 
Kumar S, Singh SP, Mishra IM, Adhikari DK (2009b) Ethanol and Xylitol production from glucose and xylose at high temperature by Kluyveromyces sp. IIPE453. J Ind Microbiol Biotechnol 36:1483-1489

Lodolo EJ, Kock JLF, Axcell BC, Brooks M (2008) The yeast Saccharomyces cerevisiae - the main character in beer brewing. Fems Yeast Res 8:1018-1036

Magesh A, Preetha B, Viruthagiri T (2011) Statistical optimization of process variables for direct fermentation of 226 white rose tapioca stem to ethanol by fusarium oxysporum. Int J Chem Tech Res 3:837-845

Man HL, Behera SK, Park HS (2010) Optimization of operational parameters for ethanol production from korean food waste leachate. Int J EnvSci Tech 7:157-164

Maruthai K, Thangavelu V, Kanagasabai M (2012) Statistical screening of medium components on ethanol production from cashew apple juice using Saccharomyces Diasticus. Int J Chem Biol Engg 6:108-111

Mei X, Liu R, Shen F, Cao W, Wu H, Liu S (2011) Optimization of solid-state ethanol fermentation with the soluble carbohydrate in sweet sorghum stalks using response surface methodology. J Biobased Mater Bio 5:532-538

Muntz JA (1947) The role of potassium and ammonium ions in alcoholic fermentation. J Biol Chem 17:653-665

Ohtani K (2000) Bootstrapping $R^{2}$ and adjusted $R^{2}$ in regression analysis. Econ Model 17:473-483

Palukurty MA, Telgana NK, Bora HSR, Mulampaka SN (2008) Screening and optimization of metal ions to enhance ethanol production using statistical experimental designs. Afr J Microbio Res 2:87-94

Plackett RL, Burman JP (1946) The design of optimum multifactorial experiments. Biometrika 33:2147-2157

Rodriguez-Vazquez R, Villanueva-Ventura G, Rios-Leal E (1992) Sugarcane bagasse pith dry pretreatment for single cell protein production. Bioresour Technol 39:17-22

Sanjuan R, Anzaldo J, Vargas J, Turrado J, Patt R (2001) Morphological and chemical composition of pith and fibres from mexican sugarcane bagasse. HolzalsRoh-Und Workestoff 59:447-450

Sasikumar E, Viruthagiri T (2008) Optimization of process conditions using response surface methodology (rsm) for ethanol production from pretreated sugarcane bagasse: kinetics and modeling. Bioenerg Res 1:239-247

Saxena RC, Adhikari DK, Goyal HB (2009) Biomass-based energy fuel through biochemical routes: a review. Renewab Susta Ener Rev 13:167-169

Sharma N, Kalra KL, Oberoi HS, Bansal S (2007) Optimization of fermentation parameters for production of ethanol from kinnow waste and banana peels by simultaneous saccharification and fermentation. Indian J Microbiol 47:310-316

Uncu ON, Cekmecelioglu D (2011) Cost-effective approach to ethanol production and optimization by response surface methodology. Waste Manage 31:636-643

Wan P, Zhai D, Wang Z, Yang X, Tain S (2012) Ethanol production from nondetoxified dilute-acid lignocellulosichydrolysate by cocultures of Saccharomyces cerevisiae Y5 and Pichiastipitis CBS6054. Biotechnol Res Int:1-6

doi:10.1186/2193-1801-2-159

Cite this article as: Dasgupta et al:: Design and optimization of ethanol production from bagasse pith hydrolysate by a thermotolerant yeast Kluyveromyces sp. IIPE453 using response surface methodology. SpringerPlus 2013 2:159.

\section{Submit your manuscript to a SpringerOpen ${ }^{\circ}$ journal and benefit from:}

- Convenient online submission

- Rigorous peer review

- Immediate publication on acceptance

- Open access: articles freely available online

- High visibility within the field

- Retaining the copyright to your article

Submit your next manuscript at $\gg$ springeropen.com 